\title{
Character Education Application in Thematic-Integrative Learning of Curriculum 2013
}

\author{
Hani Dwi Hastuti ${ }^{1}$ (*), Marsigit ${ }^{2}$ \\ Universitas Negeri Yogyakarta, Indonesia
}

$\begin{array}{ll}\text { Received: } & \text { September 18, } 2019 \\ \text { Revised: } & \text { October 13, } 2019 \\ \text { Accepted: } & \text { February 05, } 2020\end{array}$

Accepted: February 05, 2020

\begin{abstract}
This research development aimed to produce thematic-integrative teaching materials based on a scientific approach. The product produced aimed to develop a confident character. Teaching materials developed got positive responses from students with excellent task completion achievement, amounting to $81.5 \%$. This was evidenced based on the results of expert assessments which showed that teaching material developed from the content eligibility aspect was categorized as "very good" with an average of 64.5, aspects of language were categorized as "good" with an average of 31 , aspects of presenting the category of "very good" with an average of 59 , and the aspect of graphics categorized as "very good" with an average of 55. Thematic-integrative teaching materials based on a scientific approach with the theme "Beautiful Togetherness" to develop selfconfidence and improve learning outcomes of grade IV elementary school students in learning.
\end{abstract}

Keywords: Teaching, Development, Scientific, Thematic-Integrative

(*) Corresponding Author:

hanihastuti07@gmail.com

How to Cite: Hastuti, H.D. \& Marsigit, M. (2020). Character education application in thematic-integrative learning of curriculum 2013. Formatif: Jurnal Ilmiah Pendidikan MIPA, 10 (1): 35-46. http://dx.doi.org/10.30998/formatif.v10i1.4735

\section{INTRODUCTION}

In the 2013 curriculum, thematic-integrative learning uses a scientific approach. The scientific approach is believed to be the main step in the development and development of students' attitudes, skills, and knowledge (Octaviani, 2017). Thematic-integrative learning that integrates various subject concepts into a particular theme can be carried out with a scientific approach to achieving the learning objectives so that meaningful learning is carried out. The scientific approach refers to investigative techniques for phenomena or symptoms, gaining new knowledge, or correcting and integrating prior knowledge. These things are by the core of thematic-integrative learning (Junaidi, 2018; Murfiah, 2017; Setyowati \& Mawardi, 2018)

The application of thematic-integrative learning has implications for several parties and components in the learning process, as explained by Rusman (in Hasanah, 2017) that the use of thematic models has implications for the creation of learning and learning situations, namely the application of thematic learning models in primary schools requiring teachers to be creative and innovative so that teaching and learning activities become more meaningful and whole; in the application of the thematic learning model students are first made aware of the importance of linking curriculum material / content to each learning; demanded the availability of textbooks that integrate between one subject with other subjects, and with life; and required the availability of media that can support the thematic learning process (Segoro, Sapto, \& Yuniastuti, 2019) 
Based on the results of an interview on Saturday $3^{\text {rd }}$ May 2014 at 10.05 WIB with one of teacher at SD Negeri 49 Kota Bima, he said that the presence of the 2013 curriculum motivated teachers to do better learning, but the lack of knowledge about thematicintegrative learning with an approach Scientists dampen their good intentions a little. SDN 49 City Bima students who have diverse abilities, so far have referred to learning that prioritizes memorization, without regard to the process of achieving results. The lack of creative ideas of teachers in using and linking things around students during the learning process to achieve learning objectives is one of the factors that make them of SDN 49 Kota Bima pay less attention to the learning process and only prioritize the result by memorization. Besides, the implementation of the 2013 curriculum seems to be lacking preparation, teachers are only given short training that has not been enough to answer some fundamental questions about the 2013 curriculum, such as how to evaluate student abilities. Aside from the teacher, for grade IV students who have never been introduced to thematic learning feel confused about the change from lessons that are limited by subjects to unlimited learning and are linked by one theme.

In the follow-up interview, other facts emerged in the learning activities that most students lacked self-confidence, such as not being able to do their work, always asking friends and teachers, and they doing assignments not on time and often imitating the work of other friends. This reminds that the importance of the value of confidence so that students can control their behavior. The character of confidence is expected to be able to emerge in students when learning takes place, the courage of students to express their ignorance in questioning activities and in conveying an idea (Junaidi, 2018). Thematic-integrative learning with a scientific approach prioritizes learning centers in students, so it is indirectly assumed to be able to develop the confidence of students who are the main actors in the learning process.

Character education that is aligned with the learning process is an effort to prevent students to take less moral actions. Character education is an attempt to educate children to be able to make wise decisions and practice them in their daily lives so that they can make a positive contribution to their environment. Amid the diversity of society today, we need a business that can develop students' self-potential by balancing with the prevailing norms. One of the values, that must be developed in the character education of students is the value of students' self-confidence so that all the courage of students who are a mirror of selfconfidence can be limited so that it does not become one of the causes of unscrupulous acts such as fights between students. (Saidah \& Damariswara, 2017)

Books are media that can be used as teaching material. Textbooks that are utilized in learning as a standard reference in certain subjects. The average textbooks used by students as learning resources are published by the Ministry of Education and Culture. Strengthened in the study of Wijiningsih \& Wahjoedi (in Segoro et al., 2019) that to motivate student learning teachers can choose a variety of learning media so that the learning delivered will be more meaningful (Budiani, Sudarmin, \& Syamwil, 2017). This research will develop the teaching materials needed by SDN 49 Bima City teachers, namely thematic-integrative teaching materials based on a scientific approach following the 2013 curriculum. The teaching materials developed are integrating knowledge with selfconfidence, and contained in a theme that is the theme "The Beauty Togetherness".

\section{METHOD}

This research is a Research and Development in the field of education which aims to produce thematic-integrative teaching materials based on a scientific approach to 
develop the confidence of elementary school class IV students (Saputri \& Mawardi, 2017). The development model used in this study was adapted from the Borg \& Gall model (1983: 775) whose procedure consisted of ten steps. The ten steps are: (a) Collecting information and conducting preliminary research, (b) Planning, (c) Developing a format or model, (d) Field testing, (e) Revision of tests based on the results of field trials , (f) Field tests, (g) Revisions after getting input from field tests (operational product revision), (h) Model test trials or learning tests (i) Final revisions, (j) Submission of research reports. The product produced aims to develop a confident character. This research produces a product and tests the effectiveness of the product produced so that it only passes the first research step until the ninth. In the implementation, this research is completed with syllabus and lesson plans. The flow of research that has been done is presented in Figure 1.

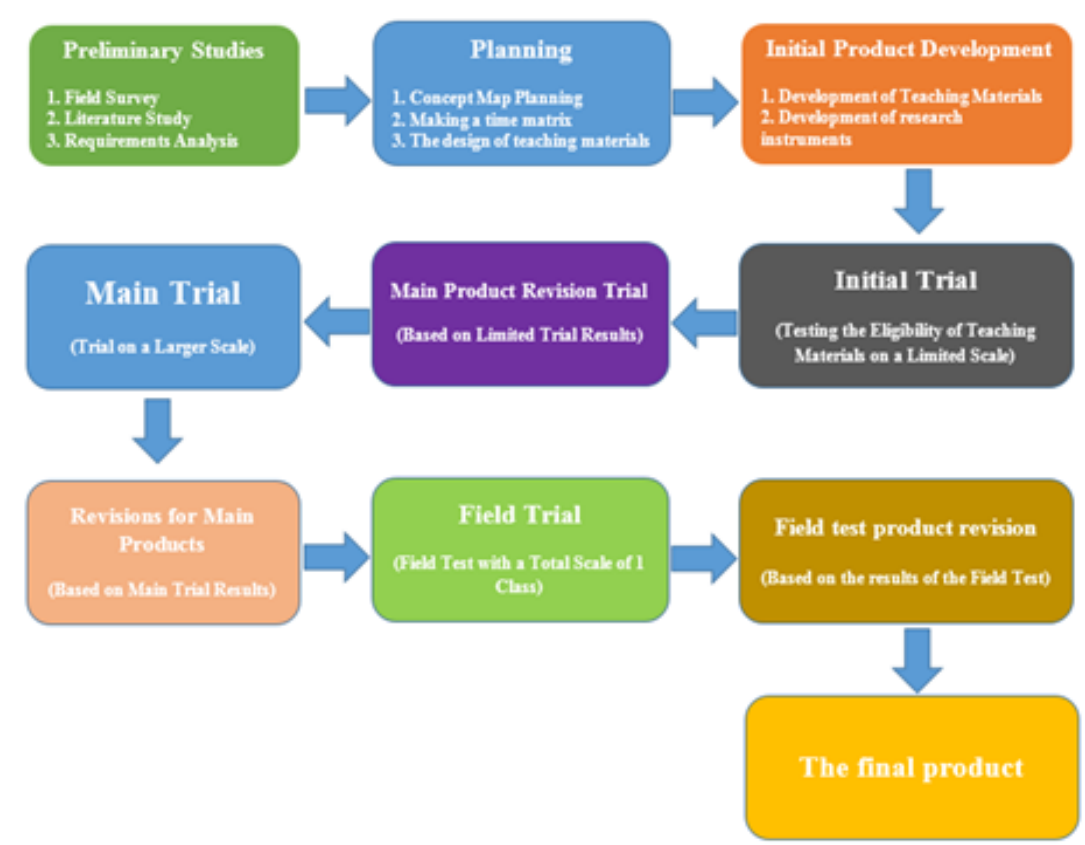

Figure 1. Development Research Flow (Source: Borg \& Gall, 1983: 775-776)

\section{RESULTS AND DISCUSSION}

\section{Results}

The first stage after preparing the teaching material is product validation. Product validation is an assessment of product quality by experts. Expert validation data was obtained by providing an initial product in the form of thematic-integrative teaching materials with the theme "Beautiful Togetherness" based on a scientific approach for students in grade IV SDN 49 Bima City to two experts, in this study, Prof. Dr. Djukri (expert 1) and Dr. Heri Retnawati (expert 2). Validation data acquisition using a thematicintegrative teaching material questionnaire based on a scientific approach that includes aspects of assessment, namely aspects of content eligibility, linguistic aspects, presentation aspects, and graphic aspects. (Octaviani, 2017; Segoro et al., 2019)

The assessments results done by the expert concluded that the aspects of the appropriateness of the contents that contained conformity to basic competencies, conformity to child development, the need for teaching materials, the truth of teaching 
materials, were useful for adding insight and conformity with social morals included in the excellent category with an average of 64.5 Linguistic aspects related to readability, clarity of information, conformity with good and correct Indonesian language rules, and effective and efficient use of language in good categories with an average of 31. The presentation aspects of teaching materials contain clarity of objectives to be achieved, the order of presentation, giving motivation and attractiveness, interaction, and completeness of information in the category is very good with an average of 59. The graphic aspects related to the use of fonts, layouts, illustrations, pictures and photos, and display design are in the very good category with an average of 53 . All assessment aspects reach both good and very good categories, so it can be concluded that the thematic-integrative teaching materials based on a scientific approach with the theme "Beautiful Togetherness" deserve to be used in research. In addition to providing ratings with rating scales, experts as validators also provide suggestions and comments for improving the quality of teaching materials. The suggestions and comments were given by experts (a) In some parts need to be revised the materials concepts, (b) It needs to be revised a few sentences about the editorial and environmental style, (c) the substance improvement in the book and (d) Note the substance of the assessment. Based on these criticisms and suggestions revised teaching materials to improve the teaching material developed quality. After the revision, the product developed in the form of thematic-integrative teaching materials based on a scientific approach with the theme "The Beauty of Togetherness" can be tested.

In the initial trial given to four students of class IV B SDN 49 Bima City, to find out the weaknesses and strengths of thematic-integrative teaching materials based on a scientific approach with the theme "The Beauty of Togetherness". Students selected in this initial trial were two boys and two girls, and with varying degrees of ability according to the level of achievement and advice of grade IV B teachers at SDN 49 Bima City. In this initial trial process, students are given a pretest that contains subject matter that has been studied previously. After conducting the pretest the teacher implements learning according to the thematic-integrative learning plan based on the scientific approach, and students who become the test subjects use the thematic-integrative teaching material based on the scientific approach with the theme "Beautiful Togetherness". (Gultom, Situmorang, \& Silaban, 2015)

During the learning, observations process are made on the implementation of learning with a scientific approach, confident character values. At the end of the learning process, students are given a questionnaire on self-confidence evaluation, a post-test in written form, and an examination of teaching materials as an assessment of students' performance. Next, the researcher analyzed the results of the initial trial. The data obtained in the initial trial are pretest data, the implementation observations of learning based on a scientific approach, confident observations, student character assessment questionnaire, posttest results, and performance assessment results. The analysis results of the thematicintegrative learning implementation based on a scientific approach with teaching materials developed in the good category with a percentage of the total performance of $77.4 \%$. The implementation of scientific-based learning in both categories so that the developed teaching materials can help teachers to apply to learn based on a scientific approach.

The students' self-assessment data results using thematic-integrative teaching materials based on scientific approaches in both categories. For the observing self-esteem aspect with an average score of 16, students can position themselves to be worthy of happiness and success. Aspects of observing competencies are also in the good category with an average score of 21 , students have the confidence to achieve, solve problems, and think for themselves. Likewise, with the observation aspect of achieving good category with an average score of 16 , students have a feeling of being accepted, valued, and thinking 
for themselves. Data on the results of students' confidence assessment using thematicintegrative teaching materials based on a scientific approach are presented in Table 1.

Table 1. Data on the results of self-assessment

\begin{tabular}{llcccccc} 
& \multirow{3}{*}{ No } & $\begin{array}{c}\text { Observation } \\
\text { Aspects }\end{array}$ & \multicolumn{4}{c}{ Score } & \multicolumn{3}{c}{$\begin{array}{c}\text { Average Score } \\
\text { (X) }\end{array}$} & Category \\
\cline { 3 - 6 } & & A & B & C & D & & \\
\hline 1 & Pride & 18 & 15 & 14 & 17 & 16 & Good \\
2 & Competence & 20 & 20 & 19 & 19 & 21 & Good \\
3 & Ownership & 17 & 16 & 16 & 15 & 16 & Good \\
\hline
\end{tabular}

Another component used to determine the effectiveness of teaching materials used to improve student learning outcomes is to look at the pretest, posttest, and assessment of student performance on teaching materials. The results of the pretest and posttest data were compared with the Minimum Mastery Criteria (KKM) of SDN 49 Bima City, which is 75 to determine the completeness of students after using thematic-integrative teaching materials based on a scientific approach with the theme "Beautiful Togetherness". The results of the Confidence Assessment in the Initial Trial are presented in table 2.

Table 2. Confidence Assessment Results in the Initial Trial

\begin{tabular}{cccccc}
\hline \multirow{2}{*}{ No } & \multirow{2}{*}{ Student } & \multicolumn{2}{c}{ Value } & Completeness & \multirow{2}{*}{ Information } \\
\cline { 3 - 4 } & & Pre-test & Post-test & Criteria & \\
\hline 1 & A & 82 & 83 & Complete & Increase \\
2 & B & 66 & 80 & Complete & Increase \\
3 & C & 73 & 78 & Complete & Increase \\
4 & D & 65 & 80 & Complete & Increase \\
\hline
\end{tabular}

After the use of teaching materials developed there is an increase in the value of the four students with different differences and the four students can achieve the KKM value as a standard of mastery learning. In addition to the written test on the pretest and posttest, the assessment of student learning outcomes also uses a performance assessment sheet that is the results of the students' activities on teaching material. This performance evaluation is also an assessment of the process. The results of student performance appraisal in the initial trial are presented in table 3.

Table 3. Results of student performance appraisal in the initial trial

\begin{tabular}{|c|c|c|c|c|c|}
\hline \multirow{2}{*}{ No. } & \multirow{2}{*}{ Student } & \multicolumn{2}{|c|}{ Learning } & \multirow{2}{*}{$\begin{array}{c}\text { Percentage of } \\
\text { Achievement }(\%)\end{array}$} & \multirow{2}{*}{ Category } \\
\hline & & 1 & 2 & & \\
\hline 1. & A & 27 & 34 & 87,1 & Very Good \\
\hline 2. & B & 21 & 22 & 61,4 & Good \\
\hline 3. & C & 24 & 28 & 74,2 & Good \\
\hline 4. & D & 19 & 30 & 70 & Good \\
\hline
\end{tabular}

Based on table 3, it can be seen that the achievement of a student completes the assignment of teaching materials developed in the excellent category with a accomplishment percentage of $87.1 \%$, and three other students reach the good category. The performance results evaluation of the four students showed that students' responses to the teaching materials developed were also good, namely, they received teaching materials developed as a source of learning and wanted to complete the assignment of teaching 
materials. Student learning outcomes improvement based on pretest and posttest were written tests as well as student performance achievement results in teaching materials in very good and good categories indicates that scientific-thematic-integrative teaching materials developed are effective against improving student learning outcomes in early trials.

Infield trials conducted in class IV B SDN 49 City of Bima by selecting ten students who were not involved in the initial trial. The teacher gives a pretest with material that has been studied previously and is based on consultation with the class teacher. Then the teacher carries out the learning process with a scientific approach with ten students using thematic-integrative teaching materials based on a scientific approach with the theme "Beautiful Togetherness". During the learning process observations of the students' selfconfidence character are observed. At the end of the lesson, a self-assessment questionnaire related to self-confidence was given, a posttest in the form of a written test and seeing the performance of the participants with the teaching material developed.

The data obtained in the field trials in the form of observations of the implementation of learning data with a scientific approach, confidence character, students self-assessment questionnaire, the results of the pretest and posttest, as well as the results of the student's performance evaluation at the field trial stage. The results of observations of the implementation of thematic-integrative learning with a scientific approach with teaching materials developed in the form of scores are then summed from each observer then converted into a percentage of the maximum score and categorized in the conversion of learning accomplishments. The results of the Thematic Integrity Analysis-Integrative Learning Based on Scientific Approaches in Field Trials are presented in table 4.

Table 4. Analysis Results of the Implementation of thematic-integrative learning based on a scientific approach to field trials

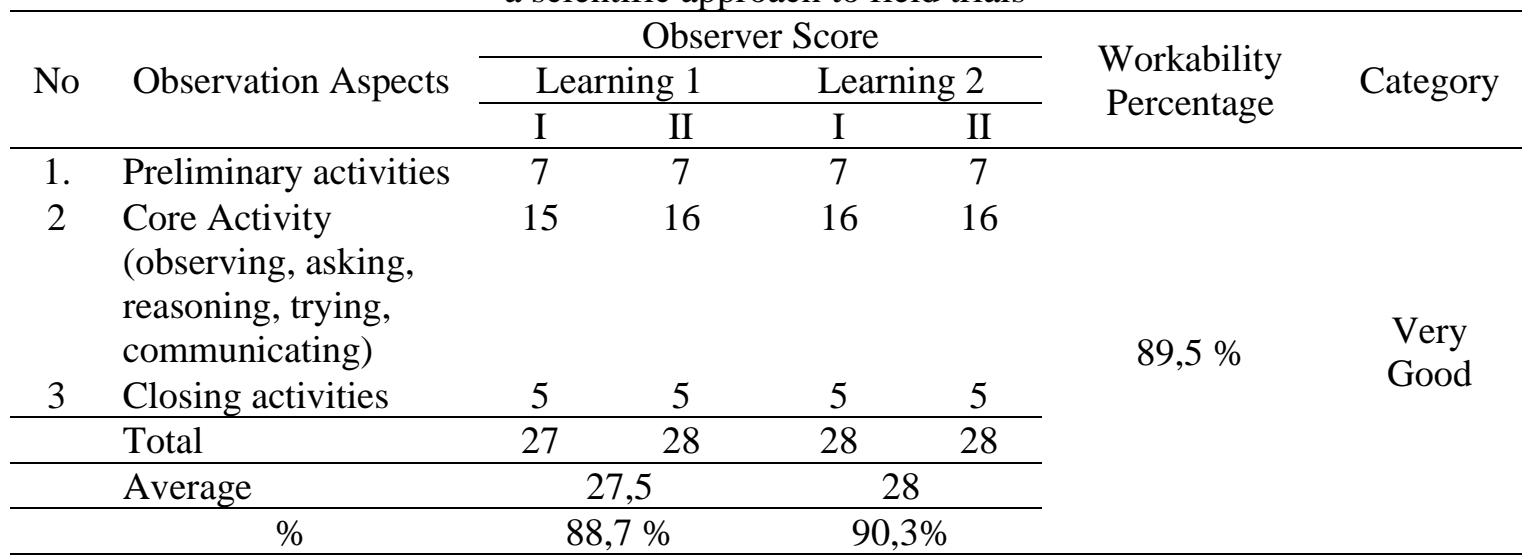

The results of the students' self-assessment of their confidence, based on the results of the questionnaire can be seen in table 5

Table 5. The results of students' self-assessment of each other's confidence

\begin{tabular}{clcc}
\hline \multirow{2}{*}{ No } & \multirow{2}{*}{ Observation Aspects } & $\begin{array}{c}\text { Average Score } \\
(\mathrm{X})\end{array}$ & \multirow{2}{*}{ Category } \\
\hline 1 & Pride & 18 & Very Good \\
2 & Competence & 20 & Good \\
3 & Ownership & 17 & Very Good \\
\hline
\end{tabular}


Based on table 5, it appears that the average score for groups of students using scientific-thematic-integrative teaching materials in the category of "very good" for the aspects of self-esteem and ownership observation. They are very good at putting themselves to be happy and successful and can be accepted and valued by others. As for the aspect of observing competencies in the "good" category, some students are still unsure of themselves in solving problems. In addition to the students' self-confidence, they must also balance their self-esteem, competence, and ownership with their respective selves, so that there is no excess self-confidence that can adversely affect students.

Not only the development of student confidence a condition of the effectiveness of teaching materials developed in this study, but the effect of teaching materials on improving student learning outcomes must also be considered. The assessment of student learning outcomes can be seen from the pretest and posttest with written questions, as well as assessing the performance of students on teaching materials. The results of the analysis of learning outcomes are also adjusted to the Minimum Mastery Criteria of SDN 49 Bima City, which is 75. Data from the students' pretest and posttest assessment in the field trials are presented in Table 6.

Table 6. Results of students' pretest and posttest assessments in field trials

\begin{tabular}{lccccc}
\hline \multirow{2}{*}{ No } & \multirow{2}{*}{ Students } & \multicolumn{3}{c}{ Value } & Completeness \\
\cline { 2 - 4 } & & Pre-test & Post-test & Criteria & \\
\hline 1 & A2 & 73 & 85 & Completed & Increased \\
2 & B2 & 80 & 92 & Completed & Increased \\
3 & C2 & 72 & 83 & Completed & Increased \\
4 & D2 & 90 & 96 & Completed & Increased \\
5 & E2 & 85 & 90 & Completed & Increased \\
6 & F2 & 67 & 82 & Completed & Increased \\
7 & G2 & 92 & 93 & Completed & Increased \\
8 & H2 & 77 & 86 & Completed & Increased \\
9 & I2 & 63 & 87 & Completed & Increased \\
10 & J2 & 85 & 91 & Completed & Increased \\
\hline
\end{tabular}

Based on pretest and posttest results of students in field trials it can be concluded that by using thematic-integrative teaching materials based on a scientific approach all students can be able to achieve the KKM value. At the pretest, $40 \%$ of students were unable to reach the completeness score but an increase in the posttest. For all students who use teaching materials developed there is an increase in the value of learning outcomes with different differences. In addition to improving learning outcomes from pretest and posttest data in field trials, there is also an assessment of student learning outcomes using performance assessments on teaching materials that can be a reference. In the student performance appraisal results in field trials, there was an increase in the achievement percentage at this field trial stage compared to the initial trial stage, ie the maximum percentage reached $90.9 \%$ while at the initial trial stage only reached $87.1 \%$ there was a difference achievement of $3.8 \%$. As for the minimum percentage of achievement there was also an increase, namely at the initial trial stage the minimum percentage of the four students was only $61.4 \%$, and at the field trial stage the minimum percentage of achievement of the ten students was able to reach above $70 \%$ namely precisely $74,6 \%$ there is a difference in achievement of $13.2 \%$. Achievement of the minimal category both in field trials and an increase in the percentage of achievement in assessing student performance compared to this initial trial phase explains that the interest of students in teaching materials developed is increasing. 
In carrying out field tests the development of thematic-integrative teaching materials based on a scientific approach with the theme "Beautiful Togetherness" to develop self-confidence and improve learning outcomes of class IV SDN 49 students in Bima City involves two classes namely class IV A as a control class and class IV B as an experimental class. The research subjects for this field trial were 24 students from class IV A and 24 students from class IV B. At this stage the study was conducted with a pretestposttest control group design. The thematic-integrative teaching materials based on the scientific approach with the theme "Beautiful Togetherness" used at this stage have been revised by the initial trials and field trials. The research initial step at this stage is the provision of a pretest in the form of written questions to students in class IV A and IV B and in the first learning self-confidence observations are carried out in both classes to determine the initial conditions. After carrying out a written pretest and observing student behavior, in learning the two teachers carry out learning by using thematic-integrative teaching materials based on a scientific approach in class IV B as an experimental class, and in-class IV A learning takes place using only the 2013 curriculum textbooks from the government. During the learning, process observations are carried out on the implementation of thematic-integrative learning with a scientific approach, observing the students 'confident character, and evaluating students' performance. At the end of the sixth lesson, a posttest is given in the form of a written test or evaluation sheet on teaching materials and interviews with students regarding the use of thematic-integrative teaching materials based on a scientific approach with the theme "Beautiful Togetherness".

Field test results data in the form of data on the results of the implementation of thematic-integrative learning based on a scientific approach, the results of the pretest in the form of written tests and observations of confident characters, observation of characters during the learning process and posttest results in the form of written tests. Learning in both classes using a scientific approach. The results of the analysis of the implementation of thematic-integrative learning based on a scientific approach to both classes in table 7 .

Table 7. The results of the analysis of the feasibility of thematic-integrative learning based on a scientific approach in both classes

\begin{tabular}{ccccccccc}
\hline \multirow{2}{*}{ No. } & Class & \multicolumn{4}{c}{ Learning } & Performance & Category \\
\cline { 2 - 6 } & & 1 & 2 & 3 & 4 & 5 & Percentage & IV A \\
\hline 1 & 20 & 18 & 21 & 22 & 19 & $64,5 \%$ & Good \\
2 & $\begin{array}{c}\text { (Control Class) } \\
\text { IV B }\end{array}$ & 25 & 26 & 25 & 24 & 27 & $81,9 \%$ & Very Good \\
\hline
\end{tabular}

The thematic-integrative learning analysis results based on the scientific approach in table 7 are tabulations of the average scores of the two observers compared to the total points, then converted into percentages. In this field test, the difference between the percentage of the implementation of thematic-integrative learning with the scientific approach in both classes was $17.4 \%$, the percentage of implementation in the control class (IV A) was $64.5 \%$ with a good category while in the experimental class (IV B) it was able reached $81.9 \%$ in the excellent category. This explains that the use of scientific-based thematic-integrative teaching materials affects the implementation of learning in the classroom.

Based on the results of confidence observations at the field test stage presented in table 7, data analysis was performed using independent t-test analysis with the help of SPSS Statistics 17.0 to determine whether there were differences in the character of confidence 
in the two classes (control and experiment). The t-test analysis results for the confidence character can be seen in table 8

Table 8. t-test analysis results for confident characters

\begin{tabular}{ccccc}
\hline Data & $\mathrm{t}$ count & $\mathrm{t}$ table & Sig (2-tailed) & Conclusion \\
\hline Pre-test & $-0,384$ & 2,0129 & 0,704 & There is no difference \\
Post-test & $-6,620$ & 2,0129 & 0.000 & There is a difference \\
\hline
\end{tabular}

From the data of the t-test results the confidence character shows that $t$ _count $<\mathrm{t}$ table $(-6.620<2.0129)$ with a significance level of 5\% so that $\mathrm{H} \_0$ is rejected, which means that there is a difference between the confident observations of the control class and the experimental class. So there is a difference in the character of confidence between classes that use teaching materials that are developed with classes that only use teaching materials from the government. Differences in the character of students' confidence in the experimental class and the control class are shown in table 7. Based on the results of the ttest data analysis which states the differences in the development of confidence between the control class and the experimental class, as well as with a description of the difference in the experimental class an increase and results if there is greater confidence than the control class, it can be stated that the thematic-integrative teaching material based on the scientific approach used in the experimental class is effective in developing the confidence of students.

One of the learning goals is to increase the students ability in the form of student learning outcomes, so in addition to developing the character of confidence, that has been declared effective must also be seen the influence of teaching materials developed towards improving student learning outcomes. The student learning outcomes data in the field test are presented in table 9. Data analysis was performed using an independent t-test analysis with the help of SPSS Statistics 17.0, this was done to determine whether there were differences in student learning outcomes between the control class and the experimental class. The t-test analysis data can be seen in table 9 .

Table 9. t-test analysis results

\begin{tabular}{ccccl}
\hline Data & $\mathrm{t}$ count & $\mathrm{t}$ table & Sig (2-tailed) & Conclusion \\
\hline Pre-test & 0,390 & 2,0129 & 0,698 & There is no difference \\
Post-test & $-4,000$ & 2,0129 & 0.000 & There is a difference \\
\hline
\end{tabular}

From the t-test data of student learning outcomes in the field test shows that t_count $<t-t a b l e ~(-4,000<2.0129)$ so that $H_{-} 0$ is rejected, which means that there is a difference between the learning outcomes of the control class and the experimental class. So there are differences in learning outcomes between classes that use teaching materials that are developed with classes that only use teaching materials from the government. In the experimental class, there was an increase in learning outcomes between pretest and posttest by $100 \%$ ie all students in the experimental class experienced an increase in learning value. Whereas in the control class only those who experienced an increase in learning outcomes by $62.5 \%$, amounting to $20.83 \%$ had the same value of the results of the pretest and posttest, and there were $16.67 \%$ experienced a decrease in the value of the results of the pretest and posttest. Based on the results of the t-test analysis which states there are differences in student learning outcomes between the control class and the experimental class, and the description of the increase in student learning outcomes in the experimental class is greater and reaches $100 \%$ completeness compared to the control class, it can be concluded that the thematic-integrative teaching material based on the scientific approach used in the 
experimental class is effective against improving student learning outcomes. Other data obtained in the field test are data from the results of students' performance evaluations on teaching materials used in the experimental class. The data on the performance evaluation of students in the experimental class.

\section{Discussion}

This research is in line with research conducted by Suryanti within two years, with the title "Development of Thematic Teaching Materials to Improve the Quality of Learning in Elementary School Low Classes". The results of large-scale trials show 1) The results of large-scale trials (SD) in the city of Surabaya show that there is an effect of the application of thematic teaching materials (learning tools) on student learning outcomes; 2) There is an effect of the type of school on student learning outcomes, if learning is done with a thematic approach; 3) There is an interaction effect between types of schools and the application of thematic teaching materials to student learning achievement.

Furthermore, based on research by Busch et.al. in 2009 with the title "Two Thematic Teaching Materials for School Curriculum: A Change by Kinder Lernen Deutsch (KLD)", the study concluded that around 200 instructors in secondary schools had used thematic teaching materials in their learning classes. By using thematic teaching materials successfully connecting several subjects that can develop students' critical attitude.

Furthermore, a study by Dianna Brannon in 2008 with the title "Character Education: An approach to the value of responsibility." Research conducted in the winter developed the character of students who have a positive impact on students, especially the attitude of responsibility by producing an increase in the academic value of participants students.

Furthermore, Research by Davies \& Brown (2011) with the title "A program approach to grouping and thematic instruction". The research carried out at the secondary school level aims to prepare prospective teachers who are ready to develop competent thematic teaching materials. From the results of the study stated that by using thematicintegrative teaching materials can improve student motivation and academic assessment, and along with the changing times requires students to use higher thinking skills and participate in connecting between sciences.

Based on the study of these studies, researchers developed a teaching material in the form of printed teaching materials that integrate several subjects into a theme to provide convenience for students and by a scientific approach, namely by observing, asking, reasoning, try, and communicate. Teaching materials for grade IV students also contain the values of self-confidence and responsibility, intending to develop character education, especially self-confidence characters. In assessing the performance of students in completing assignments on teaching materials developed in the category of very good with an average percentage of the overall performance of $81.5 \%$ with the details there are 14 students or $58.3 \%$ who can reach the excellent category and 10 students or $41.67 \%$ in the good category. This explains that students' responses to teaching materials that are developed are very good. Students who use teaching materials that are developed enthusiastically and wish to complete the assignment. In line with the achievement of the completion of the assignment of teaching materials which are in the minimum category of good and as much as 58.3\% reach very good, the students' knowledge of the importance of self-confidence values. In addition to gaining the importance of self-confidence, students are asked to practice it through teaching materials developed so that students will get used to being confident. Based on these data it can be concluded the development of thematic- 
integrative teaching materials based on a scientific approach to develop self-confidence and improve learning outcomes for grade IV students at SDN 49 Bima City, proving the feasibility and effectiveness of teaching materials in developing confident character, and being able to improve the results learning grade IV elementary school students.

\section{CONCLUSION}

This research and development resulted in a product in the form of a textbook that integrates knowledge with the value of confidence, and is contained in a theme that is the theme of "The Beauty of Togetherness". Thematic-integrative teaching materials based on a scientific approach with the theme "The Beauty of Togetherness" to develop selfconfidence and improve learning outcomes of Grade IV Elementary School students is appropriate for use in learning. This is evidenced based on the results of expert assessments which show that teaching material developed from the aspect of content eligibility is categorized as "very good" with an average of 64.5, aspects of language are categorized as "good" with an average of 31 , aspects of presenting the category of "very good" with an average of 59, and the graphic aspect is "very good" with an average of 55. The effectiveness of thematic-integrative teaching materials based on a scientific approach with the theme "The Beauty of Togetherness" to develop self-confidence and improve learning outcomes of fourth-grade elementary school students as evidenced by the observation of self-confidence and student learning outcomes during the learning process. The results of observations of the confident character values show the results of the t-test of the confident character values namely $\mathrm{t} \_$count $<\mathrm{t} \_$tabel $(-6.620<2.019)$ and $\mathrm{P} 0.000<0.05$ so that $\mathrm{H}_{-} 0$ is rejected, meaning that there are differences in character values between classes using teaching materials developed with classes that only use commonly used textbooks. Student learning outcomes during the learning process using teaching materials developed has increased by $100 \%$ students thoroughly and based on the results of the pretest and posttest shows the $\mathrm{t}$-test of student learning outcomes namely t_count $<\mathrm{t}$ table $(-4,000<2.0190)$ and $\mathrm{P} 0,000<0.05$ so that $\mathrm{H} \_0$ is rejected which means there are differences in learning outcomes between classes using integrative thematic teaching materials based on the scientific approach developed. Teaching materials developed get positive responses from students with excellent task completion achievement, amounting to $81.5 \%$.

\section{REFERENCES}

Abdullah, R. (2012). Pembelajaran berbasis pemanfaatan sumber belajar. Jurnal Ilmiah DIDAKTIKA, 12(2), 216-231. http://dx.doi.org/10.22373/jid.v12i2.449

Budiani, S., Sudarmin, \& Syamwil, R. (2017). Evaluasi implementasi kurikulum 2013 di sekolah pelaksana mandiri abstrak. IJCET, 6(53), 45-57.

Faisal, E. El., \& Sulkipani, S. (2016). Pengembangan bahan ajar berbasis muatan lokal pada matakuliah pendidikan kewarganegaraan. Jurnal Civics: Media Kajian Kewarganegaraan, 13(2), 113-126. https://doi.org/10.21831/civics.v13i2.12721

Fauzi, M. (2017). Pengembangan bahan ajar berbentuk handout berbasis sejarah lokal dengan materi perjuangan rakyat Banyumas mempertahankan kemerdekaan dalam agresi militer Belanda 1 tahun 1947 terhadap minat belajar siswa kelas XI SMA Negeri 4 Purwokerto. Indonesia Journal of History Education, 5(2), 16-21.

Gultom, E., Situmorang, M., \& Silaban, R. (2015). Pengembangan bahan ajar inovatif dan interaktif melalui pendekatan saintifik pada pengajaran termokimia erdiana. Jurnal 
Pendidikan Kimia, 07(02), 49-56.

Hasanah, I. A. (2017). Implementasi Pembelajaran Tematik Integratif Pada Kelas IV MIN Kampung Baru Kabupaten Nganjuk. UIN Maulana Malik Ibrahim.

Junaidi, W. A. \&. (2018). Pendekatan saintifik: Melihat arah pembangunan karakter dan peradaban bangsa Indonesia. Epistemé: Jurnal Pengembangan Ilmu Keislaman, 12(2), 507-532. https://doi.org/10.21274/epis.2017.12.2.507-532

Kebudayaan, K. P. dan. (2016). Panduan Teknis Pembelajaran dan Penilaian di Sekolah Dasar. Jakarta: Kementrian Pendidikan dan Kebudayaan.

Murfiah, U. (2017). Model pembelajaran terpadu di sekolah dasar. Jurnal Pesona Dasar, $1(5), 57-69$.

Octaviani, S. (2017). Pengembangan bahan ajar tematik dalam implementasi kurikulum 2013 kelas 1 sekolah dasar. Eduhumaniora: Jurnal Pendidikan Dasar, 9(2), 93-98. Retrieved from http://ejournal.upi.edu/index.php/eduhumaniora/article/view/7039/4895

Saidah, K., \& Damariswara, R. (2017). Analisis bentuk bentuk penilaian sikap siswa sekolah dasar di kota Kediri. Profesi Pendidikan Dasar, 4(1), 84-96.

Saputri, A. T., \& Mawardi. (2017). Pengembangan desain pembelajaran tematik integratif berbasis pendekatan contextual teaching and learning (CTL) kelas 4 sekolah dasar. Jurnal Imiah "Pendidikan Dasar", IV(2), 104-114.

Segoro, B., Sapto, A., \& Yuniastuti. (2019). Buku Ajar Tematik Berbasis Muatan Lokal untuk Kelas IV Sekolah Dasar. Journal.Um.Ac.Id, 4(1), 1-5.

Setyowati, N., \& Mawardi, M. (2018). Sinergi project based learning dan pembelajaran bermakna untuk meningkatkan hasil belajar matematika. Scholaria: Jurnal Pendidikan Dan Kebudayaan, 8(3), 253-263. https://doi.org/10.24246/j.js.2018.v8.i3.p253-263

Utari, U., \& Degeng, I. N. S. (2016). Pembelajaran tematik berbasis kearifan lokal di sekolah dasar dalam menghadapi masyarakat ekonomi asean (MEA). Jurnal Teori dan Praksis Pembelajaran IPS, 1(1), 39-44.

Wijiningsih, N., \& Wahjoedi. (2017). Pengembangan bahan ajar tematik berbasis budaya lokal, Jurnal Pendidikan: Teori, Penelitian, \& Pengembangan, 2, 1030-1036.

Windyariani, S., Setiono., \& Sutisnawati, A. (2016). Pengembangan bahan ajar berbasis konteks dan kreativitas untuk melatihkan literasi sains siswa sekolah dasar. Jurnal Bioedukatika, 4(2), 19-25. http://dx.doi.org/10.26555/bioedukatika.v4i2.5326 